\title{
2012 年度香港・マカオ日本語能力試験実施報告 \\ Report on JLPT, 2012 (Hong Kong and Macau)
}

\section{劉 礪志 \\ 日本語能力試験実施委員会 担当理事}

\section{1. はじめに}

前年度の新日本語能力試験と比心゙、今年の応募者がおよそ $12 \%$ 減少した。もつと さかのぼり、新試験が実施される前の 2009 年旧試験（1 級-4 級）のデータと見比心゙ ると、36\%減という更に驚くべき数字が見えてきた。

新試験へ切り替えた初年度の学習者の減少現象は新試験へのさまざまな配慮による もののようだったが、 3 年間の月日が経過した今も応募者数が減りつつあるというこ とは、日本語学習はもちろん、日本そのものに対するイメージに対し変化が出てきて いるということであるに違いない。原因を探るための一つのヒントとして、12 月の 試験応募者を対象に行われた、宇田川洋子先生の「香港の日本語能力試験受験者減少 の要因を探るーアンケート調査実施報告一」を参照されたい。

\section{2012 年度の実施に関するデータ}

次は 2012 年度日本語能力試験の実施に関する報告である。

\section{1 応募手段}

日本語能力試験申込の受付センターは当香港日本語教育研究会のほかに香港日本文 化協会日本語講座と第一日語暨文化学校の 3 か所である。マカオでは 99 年よりマカ オ大学の協力を得て行われている。2005 年よりオンライン申込が可能になったとと もに、自ら受験申請のためわざわざ受付センターへ足を運ぶのを省き、好評を博しつ つあるのである。

表 1 は 05 年から 12 年までの応募者のオンライン及び受付センター申込の利用比率 である。

インターネット利用の普及、それから生活スタイルの変化とともに一層現在の人々 の生活に合ったオンライン申込システムの導入および開発などが必要であろう。 
表 12005 年 2012 年 応募手段の推移（香港・マカオ）

\begin{tabular}{|c|c|c|c|c|c|c|c|}
\hline \multirow{2}{*}{ 年度 } & \multicolumn{2}{|c|}{$\begin{array}{c}\text { ヴェブ申込 } \\
\text { (香港会場のみ) }\end{array}$} & \multicolumn{2}{|c|}{$\begin{array}{l}\text { センター申込 } \\
\text { (香港会場のみ) }\end{array}$} & \multicolumn{3}{|c|}{ 応募者数 } \\
\hline & 応募者数 & 比率 (\%) & $\begin{array}{l}\text { 応募 者 } \\
\text { 数 }\end{array}$ & 比率 $(\%)$ & $\begin{array}{l}\text { マカオ } \\
\text { 会場 }\end{array}$ & 香港会場 & 総人数 \\
\hline 05 年度 & 5,653 & 50.2 & 5,606 & 49.8 & 292 & 11,259 & 11,551 \\
\hline 06 年度 & 6,405 & 47.9 & 6,967 & 52.1 & 339 & 13,372 & 13,711 \\
\hline 07 年度 & 7,853 & 52.0 & 7,255 & 48.0 & 438 & 15,108 & 15,546 \\
\hline 08 年度 & 9,282 & 54.7 & 7,692 & 45.3 & 587 & 16,974 & 17,561 \\
\hline 09 年度第 1 回 & 2,575 & 67.5 & 1,238 & 32.5 & 0 & 3,813 & 3,813 \\
\hline 09 年度第 2 回 & 12,910 & 78.9 & 3,452 & 21.1 & 462 & 16,362 & 16,824 \\
\hline 10 年度第 1 回 & 2,836 & 82.0 & 623 & 18.0 & 0 & 3,459 & 3,459 \\
\hline 10 年度第 2 回 & 8,903 & 82.4 & 1,902 & 17.6 & 295 & 10,805 & 11,100 \\
\hline 11 年度第 1 回 & 5,037 & 83.4 & 1,000 & 16.6 & 0 & 6,037 & 6,037 \\
\hline 11 年度第 2 回 & 6,800 & 82.3 & 1,467 & 17.7 & 285 & 8,267 & 8,552 \\
\hline 12 年度第 1 回 & 4,890 & 82.8 & 1,019 & 17.2 & 0 & 5,909 & 5,909 \\
\hline 12 年度第 2 回 & 5,549 & 82.9 & 1,142 & 17.1 & 296 & 6,691 & 6,987 \\
\hline
\end{tabular}

\section{2 受験料の支払い}

三年前から利用開始の PPS（電子マネーの一種）システムの利用が下記表 2 で分か るように、小切手と比べ 8 割以上を超え、利用率が相当高い。一方、減りつつある小 切手による支払いは 12 月試験では 10 パーセントにもなっていない使用率だった。こ れは人たちが一層便利な、煩わしくない生活を求めつつある証拠かも知れない。応募 者のニーズそして新たになった生活様式に合わせ、今後新たな支払い手段を発見し検 討していきたいのである。

\section{表 22009 年 2012 年 ヴェブ申込の支払い手段の推移（香港）}

\begin{tabular}{|l|l|l|l|l|l|}
\hline \multicolumn{1}{|c|}{ 年度 } & $\begin{array}{l}\text { ヴェブ申込 } \\
\text { 人数 }\end{array}$ & $\begin{array}{l}\text { PPS で支払う } \\
\text { 人数 }\end{array}$ & 比率 $(\%)$ & $\begin{array}{l}\text { 小切手で支払う } \\
\text { 人数 }\end{array}$ & 比率 $(\%)$ \\
\hline 09 年度 & 12,910 & 10,458 & 81.0 & 2,452 & 19.0 \\
\hline 10 年度第 1 回 & 2,836 & 2,319 & 81.8 & 517 & 18.2 \\
\hline 10 年度第2 回 & 8,903 & 7,502 & 84.3 & 1,401 & 15.7 \\
\hline 11 年度第 1 回 & 5,037 & 4,445 & 88.2 & 592 & 11.8 \\
\hline 11 年度第2 回 & 6,800 & 5,925 & 87.1 & 875 & 12.9 \\
\hline 12 年度第1 回 & 4,890 & 4,355 & 89.1 & 535 & 10.9 \\
\hline 12 年度第2 回 & 5,549 & 5,028 & 90.6 & 521 & 9.4 \\
\hline
\end{tabular}




\section{劉＼cjkstart礪志：2012 年度香港・マカオ日本語能力試験実施報告}

\section{3 試験会場}

表 3 は 2012 年度試験が行われた会場である。

九龍灣国際展貿中心は最も大人数が収容可能で、場所的にもよく知られている有名 な会場である。

表 32012 年度試験会場リスト（香港・マカオ）

\begin{tabular}{|l|l|l|l|}
\hline & 会場名 & 7 月試験 & 12 月試験 \\
\hline 1 & 九龍灣国際展貿中心 3/F, Star Hal1 & $\times$ & $\bigcirc(\mathrm{N} 3$, N5) \\
\hline 2 & 九龍灣国際展貿中心 G/F, Rotunda 1 & $\times$ & $\bigcirc(\mathrm{N} 4)$ \\
\hline 3 & 九龍灣国際展貿中心 3/F, Rotunda 2 & $\times$ & $\bigcirc(\mathrm{N} 1 、 N 4)$ \\
\hline 4 & 九龍灣国際展貿中心 6/F, Rotunda 3 & $\bigcirc(\mathrm{N} 2 、 N 4)$ & $\bigcirc(\mathrm{N} 2 、 N 5)$ \\
\hline 5 & 九龍灣国際展貿中心 7/F, 会議室 & $\times$ & $\bigcirc(\mathrm{N} 3, \mathrm{~N} 4)$ \\
\hline 6 & 黄棣珊紀念中学 & $\bigcirc(\mathrm{N} 3 、 \mathrm{~N} 5)$ & $\times$ \\
\hline 7 & 銘賢書院 & $\bigcirc(\mathrm{N} 1 、 \mathrm{~N} 4)$ & $\bigcirc(\mathrm{N} 2)$ \\
\hline 8 & 恵僑英文中学 & $\bigcirc(\mathrm{N} 2)$ & $\times$ \\
\hline 9 & 聖瑪加利男女英文中小学 & $\times$ & $\bigcirc(\mathrm{N} 1)$ \\
\hline 10 & マカオ大学 & $\times(\mathrm{N} 1$ N5) \\
\hline
\end{tabular}

\section{4 応募者数及び受験者数}

表 4 は 2012 年度試験の応募者数及び受験者数のデータである。

下記データから 2012 年度試験の全体的受験率が 85 パーセント以上を超えているこ とが分かった。

表 42012 年度応募者数 - 受験者数と受験率（香港 - マカオ）

\begin{tabular}{|c|l|l|l|l|l|l|}
\hline \multirow{2}{*}{} & \multicolumn{3}{|c|}{2012 年 7 月試験 } & \multicolumn{3}{c|}{2012 年 12 月試験 } \\
\cline { 2 - 7 } & 応募者数 & 受験者数 & 受験率 $(\%)$ & 応募者数 & 受験者数 & 受験率 $(\%)$ \\
\hline N1 & 1,036 & 902 & 87.1 & 1,291 & 1,098 & 85.1 \\
\hline N2 & 1,291 & 1,129 & 87.5 & 1,378 & 1,192 & 86.5 \\
\hline N4 & 1,077 & 940 & 87.3 & 1,235 & 1,076 & 87.1 \\
\hline N5 & 1,296 & 1,136 & 87.7 & 1,592 & 1,395 & 87.6 \\
\hline 合計 & 5,909 & 1,096 & 90.7 & 1,491 & 1,345 & 90.2 \\
\hline
\end{tabular}




\section{3. 応募者に関するデータ}

受験願書より下のように応募者に関するデータが分かった。また、3.4 項から 3.8 項までは独立行政法人国際交流基金により願書に設けられたアンケート調查であり、 内容については今後変更が加わる場合があるそうである。

\section{1 性別}

表 5 は応募者の性別の比率データである。なお、図 1 の円グラフは年間の応募者全 体の比率を示している。

\section{表 52012 年度 応募者の性別（香港・マカオ）}

\begin{tabular}{|l|l|l|l|l|l|l|l|l|}
\hline \multirow{2}{*}{} & \multicolumn{5}{|c|}{2012 年 7試験 } & \multicolumn{4}{|c|}{2012 年 12 月試験 } \\
\cline { 2 - 10 } & 男性 (人) & 比率 & 女性 (人) & 比率 & 男性 (人) & 比率 & 女性 (人) & 比率 \\
\hline N1 & 389 & $37.5 \%$ & 647 & $62.5 \%$ & 474 & $36.7 \%$ & 817 & $63.3 \%$ \\
\hline N2 & 439 & $34.0 \%$ & 852 & $66.0 \%$ & 446 & $32.4 \%$ & 932 & $67.6 \%$ \\
\hline N3 & 334 & $31.0 \%$ & 743 & $69.0 \%$ & 367 & $29.7 \%$ & 868 & $70.3 \%$ \\
\hline N5 & 433 & $33.4 \%$ & 863 & $66.6 \%$ & 486 & $30.5 \%$ & 1,106 & $69.5 \%$ \\
\hline 合計 & 2,007 & $34.0 \%$ & 3,902 & $66.0 \%$ & 2,298 & $32.9 \%$ & 4,689 & $67.1 \%$ \\
\hline
\end{tabular}

図 12012 年度試験応募者性別比率（香港・マカオ）

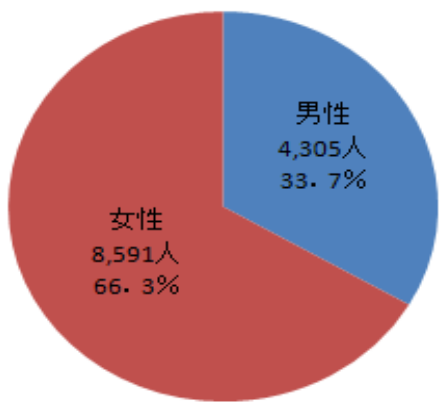

\section{2 年齢}

願書に記入された応募者のデータから、次の図 2（7 月試験）と図 3（12 月試験） で示したように、各レベルにおける応募者の年齢分布が分かった。 
劉 礪志：2012 年度香港 - マカオ日本語能力試験実施報告

図2 2012年7月試験 応募者の年喻分布図(香港)
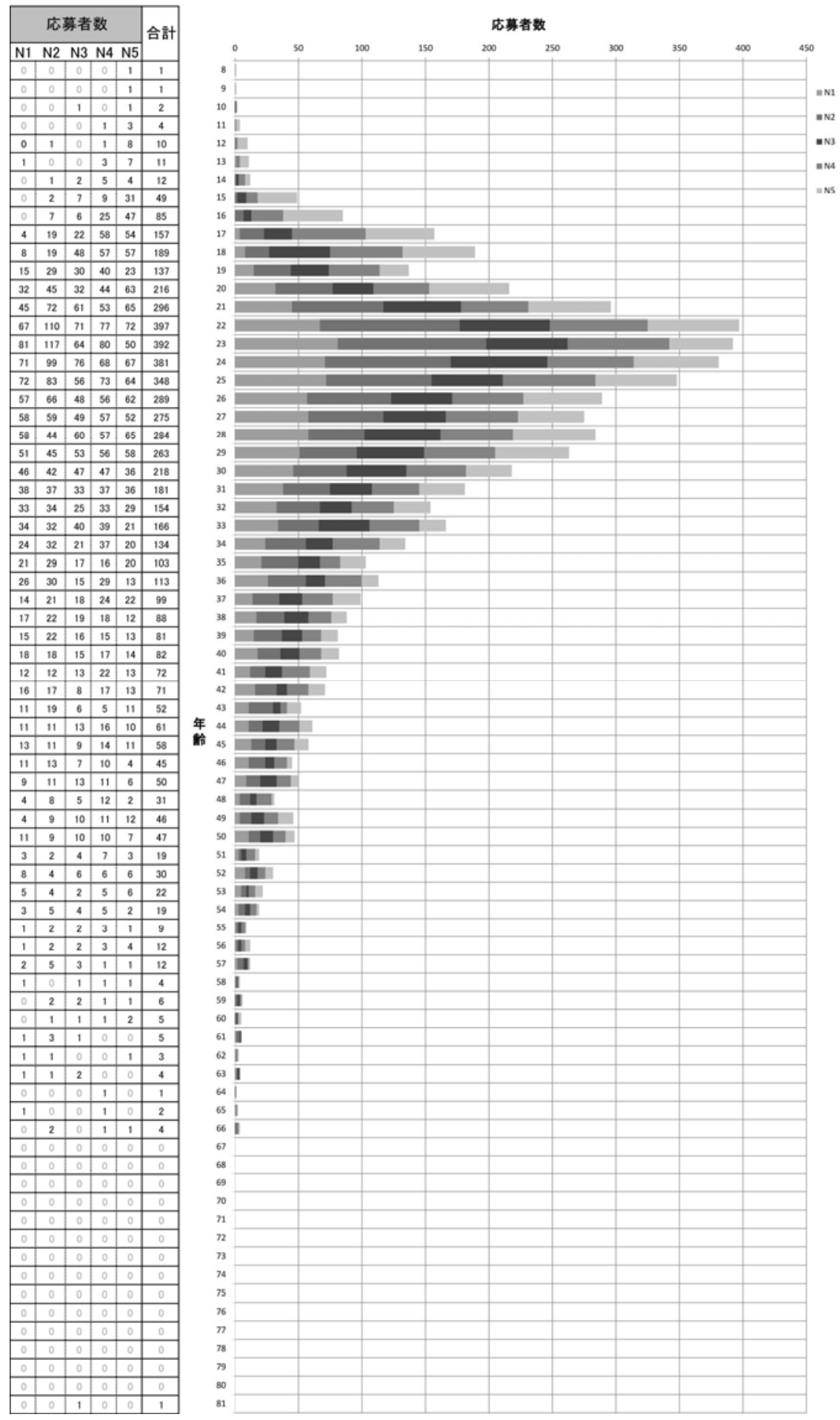
図3 2012年12 月試験 応募者の年鳐分布図(香港・マカオ)

\begin{tabular}{|c|c|c|c|c|c|}
\hline \multicolumn{5}{|c|}{ 応募者数 } & \multirow{2}{*}{ 合唁 } \\
\hline $\mathrm{N} 1$ & N2 & N3 & N4 & N5 & \\
\hline 0 & 0 & 0 & 0 & \begin{tabular}{|l|}
1 \\
\end{tabular} & 1 \\
\hline 0 & 0 & 0 & 0 & 3 & 3 \\
\hline 0 & 0 & 1 & 0 & 5 & 6 \\
\hline 0 & 0 & 1 & 0 & 2 & 3 \\
\hline 1 & 0 & 1 & 9 & 8 & 19 \\
\hline 1 & 2 & 1 & 8 & 21 & 33 \\
\hline 0 & 2 & 4 & 11 & 28 & 45 \\
\hline 1 & 2 & 13 & 29 & 55 & 100 \\
\hline 7 & 10 & 30 & 43 & $n$ & 167 \\
\hline 15 & 33 & 44 & 53 & 45 & 190 \\
\hline 15 & 33 & 45 & 43 & 43 & 179 \\
\hline 25 & 38 & 55 & 61 & 67 & 246 \\
\hline 39 & 67 & 76 & 89 & 81 & 352 \\
\hline 79 & 105 & 82 & 98 & 81 & 445 \\
\hline 92 & 97 & 61 & 85 & 70 & 405 \\
\hline 96 & 95 & 68 & 81 & 86 & 426 \\
\hline 103 & 109 & 84 & 119 & 75 & 490 \\
\hline 71 & 69 & 53 & 60 & 81 & 334 \\
\hline 84 & 54 & 79 & 85 & 87 & 389 \\
\hline 66 & 59 & 40 & 78 & 72 & 315 \\
\hline 55 & 56 & 49 & 67 & 61 & 288 \\
\hline 63 & 55 & 41 & 63 & 55 & 277 \\
\hline 47 & 48 & 48 & 55 & 47 & 245 \\
\hline 48 & 40 & 32 & 44 & 33 & 197 \\
\hline 40 & 37 & 32 & 35 & 36 & 180 \\
\hline 30 & 32 & 24 & 23 & 31 & 140 \\
\hline 30 & 30 & 25 & 34 & 19 & 138 \\
\hline 20 & 27 & 18 & 16 & 25 & 106 \\
\hline 27 & 22 & 23 & 29 & 17 & 118 \\
\hline 24 & 21 & 25 & 22 & 11 & 103 \\
\hline 18 & 25 & 20 & 24 & 16 & 103 \\
\hline 22 & 16 & 10 & 28 & 21 & 97 \\
\hline 16 & 15 & 20 & 26 & 20 & 97 \\
\hline 19 & 17 & 7 & 17 & 12 & 72 \\
\hline 21 & 21 & 12 & 13 & 12 & 79 \\
\hline 8 & 7 & 14 & 11 & 11 & 51 \\
\hline 13 & 15 & 8 & 19 & 8 & 63 \\
\hline 12 & 18 & 9 & 17 & 11 & 67 \\
\hline 16 & 20 & 11 & 10 & 5 & 62 \\
\hline 13 & 8 & 9 & 13 & 6 & 49 \\
\hline 10 & 11 & 9 & 8 & 13 & 51 \\
\hline 3 & 13 & 11 & 11 & 6 & 44 \\
\hline 9 & 7 & 7 & 6 & 2 & 31 \\
\hline 8 & 8 & 8 & 10 & 5 & 39 \\
\hline 5 & 5 & 2 & 8 & 1 & 21 \\
\hline 5 & 11 & 4 & 7 & 4 & 31 \\
\hline 2 & 3 & 3 & 3 & 4 & 15 \\
\hline 3 & 1 & 4 & 5 & 1 & 14 \\
\hline 2 & 1 & 1 & 3 & 1 & 8 \\
\hline 1 & 2 & 0 & 2 & 2 & 7 \\
\hline 2 & 1 & 2 & 1 & 4 & 10 \\
\hline 0 & 2 & 3 & 0 & 1 & 6 \\
\hline 0 & 3 & 1 & 1 & 0 & 5 \\
\hline 0 & 3 & 1 & 4 & 0 & 8 \\
\hline 2 & 0 & 1 & 0 & 0 & 3 \\
\hline 1 & 0 & 1 & 3 & 0 & 5 \\
\hline 0 & 0 & 1 & 0 & 2 & 3 \\
\hline 1 & 0 & 0 & 1 & 0 & 2 \\
\hline 0 & 1 & 0 & 1 & 0 & 2 \\
\hline 0 & 0 & 1 & 0 & 0 & 1 \\
\hline 0 & 0 & 0 & 0 & 0 & 0 \\
\hline 0 & 0 & 0 & 0 & 0 & 0 \\
\hline 0 & 0 & 0 & 0 & 0 & 0 \\
\hline 0 & 0 & 0 & 0 & 0 & 0 \\
\hline 0 & 0 & 0 & 0 & 0 & 0 \\
\hline 0 & 0 & 0 & 0 & 0 & 0 \\
\hline 0 & 0 & 0 & 0 & 0 & 0 \\
\hline 0 & 0 & 0 & 0 & 0 & 0 \\
\hline 0 & 0 & 0 & 0 & 0 & 0 \\
\hline 0 & 0 & 0 & 0 & 0 & 0 \\
\hline 0 & 0 & 0 & 0 & 0 & 0 \\
\hline 0 & 0 & 0 & 0 & 0 & 0 \\
\hline 0 & 0 & 0 & 0 & 0 & 0 \\
\hline 0 & 1 & 0 & 0 & 0 & 1 \\
\hline
\end{tabular}

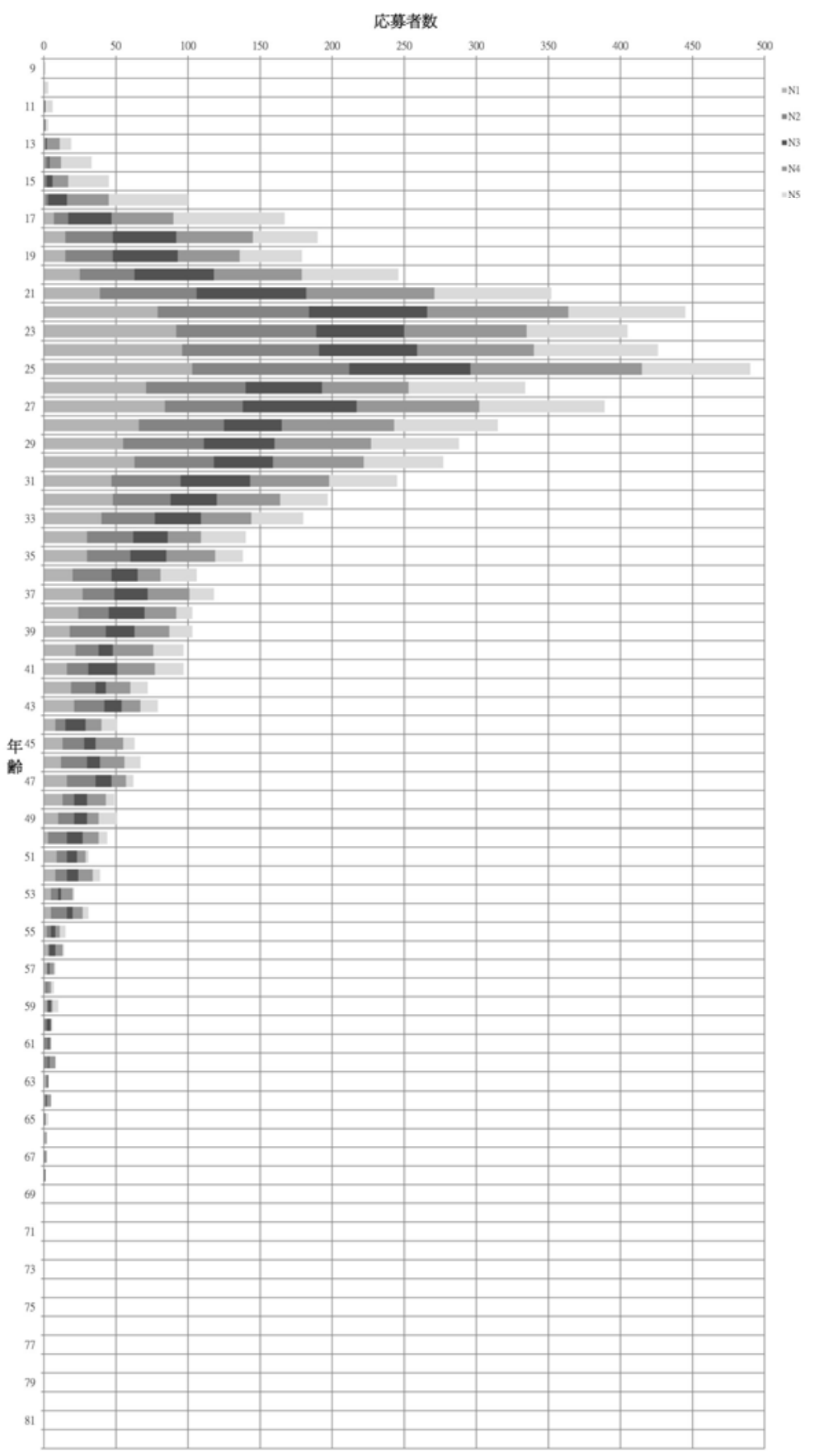




\section{劉＼cjkstart礪志：2012 年度香港・マカオ日本語能力試験実施報告}

例年と同じく応募者の多くは 20 代が占めており応募者全体の半分以上となった。 その中 8 歳の最少年者と 82 歳の最高年者受験者がそれぞれ一人、N 5 及び $\mathrm{N} 2$ に応募 したデータが分かった。

\section{3 母語}

表 6 及び表 7 は応募者の母語を示しているものである。

広東語、北京語及び他の方言を含む「中国語」を母語とする応募者の人数が全体で 99\%以上あったことが分かった。

\section{表 62012 年 7 月試験 応募者の母語（香港）}

\begin{tabular}{|l|l|l|l|l|l|l|}
\hline \multicolumn{1}{|c|}{ 母語 } & \multicolumn{1}{|c|}{ 合計 } & \multicolumn{1}{|r|}{ N1 } & \multicolumn{1}{|r|}{ N2 } & \multicolumn{1}{|c|}{ N3 } & N4 & N5 \\
\hline 中国語 (広東語) & 5,720 & 975 & 1,239 & 1,050 & 1,274 & 1,182 \\
\hline 中国語 (北京語) & 122 & 43 & 37 & 15 & 12 & 15 \\
\hline 中国語 (その他の方言) & 9 & 4 & 0 & 1 & 0 & 4 \\
\hline 英語 & 47 & 11 & 11 & 9 & 9 & 7 \\
\hline 日本語 & 3 & 1 & 2 & 0 & 0 & 0 \\
\hline フランス語 & 3 & 0 & 0 & 2 & 0 & 1 \\
\hline 韓国・朝鮮語 & 2 & 1 & 1 & 0 & 0 & 0 \\
\hline ピリピノ語 & 1 & 0 & 0 & 0 & 1 & 0 \\
\hline アイスランド語 & 1 & 1 & 0 & 0 & 0 & 0 \\
\hline スウェーデン語 & 1 & 0 & 1 & 0 & 0 & 0 \\
\hline (合計) & 5,909 & 1,036 & 1,291 & 1,077 & 1,296 & 1,209 \\
\hline
\end{tabular}

表 72012 年 12 月試験 応募者の母語（香港・マカオ）

\begin{tabular}{|l|l|l|l|l|l|l|}
\hline 母語 & 合計 & $\mathrm{N} 1$ & $\mathrm{~N} 2$ & $\mathrm{~N} 3$ & $\mathrm{~N} 4$ & $\mathrm{~N} 5$ \\
\hline 中国語 (広東語) & 6,725 & 1,210 & 1,316 & 1,196 & 1,552 & 1,451 \\
\hline 中国語 (北京語) & 165 & 53 & 48 & 28 & 23 & 13 \\
\hline 中国語 (その他の方言) & 21 & 6 & 5 & 2 & 3 & 5 \\
\hline 英語 & 63 & 20 & 6 & 8 & 10 & 19 \\
\hline フランス語 & 4 & 0 & 2 & 0 & 1 & 1 \\
\hline 韓国・朝鮮語 & 2 & 0 & 1 & 0 & 1 & 0 \\
\hline マレー語 & 2 & 0 & 0 & 0 & 2 & 0 \\
\hline 日本語 & 1 & 1 & 0 & 0 & 0 & 0 \\
\hline インドネシア語 & 1 & 0 & 0 & 0 & 0 & 1 \\
\hline ドイツ語 & 1 & 0 & 0 & 1 & 0 & 0 \\
\hline スペイン語 & 1 & 0 & 0 & 0 & 0 & 1 \\
\hline その他 & 1 & 1 & 0 & 0 & 0 & 0 \\
\hline (合計) & 6,987 & 1,291 & 1,378 & 1,235 & 1,592 & 1,491 \\
\hline
\end{tabular}




\section{4 日本語学習の場}

アンケート調査の質問 :

あなたに最も当てはまるものを一つ選んで、 $\square に$ 記入してください。 アンケートの結果 :

表 8 日本語学習の場

\begin{tabular}{|c|c|c|c|c|c|c|c|c|c|c|c|c|c|}
\hline & \multirow{2}{*}{ アンケートの選択 } & \multicolumn{6}{|c|}{ 答えの比率 \%（7月試験） } & \multicolumn{6}{|c|}{ 答えの比率 \% (12 月試験) } \\
\hline & & 全体 & N1 & N2 & N3 & N4 & N5 & 全体 & N1 & N2 & N3 & N4 & N5 \\
\hline 1 & $\begin{array}{l}\text { 現在、小学校（初等 } \\
\text { 教育）で日本語を学 } \\
\text { んでいる }\end{array}$ & 0.1 & 0.1 & 0.1 & 0.0 & 0.1 & 0.2 & 0.1 & 0.0 & 0.1 & 0.2 & 0.0 & 0.1 \\
\hline 2 & $\begin{array}{l}\text { 現在、中学校・高校 } \\
\text { (中等教育) で日本 } \\
\text { 語を学んでいる }\end{array}$ & 1.9 & 0.4 & 0.5 & 1.8 & 2.5 & 4.2 & 1.2 & 0.5 & 0.8 & 1.1 & 0.9 & 2.7 \\
\hline 3 & $\begin{array}{l}\text { 現在、大学・大学院 } \\
\text { (高等教育) の主専 } \\
\text { 攻で日本語を学んで } \\
\text { いる }\end{array}$ & 5.6 & 10.4 & 9.8 & 6.4 & 1.6 & 0.6 & 4. 7 & 9.7 & 8.0 & 4. 6 & 1.6 & 0.6 \\
\hline 4 & $\begin{array}{l}\text { 現在、大学・大学院 } \\
\text { (高等教育)の主専攻 } \\
\text { 以外で日本語を学ん } \\
\text { でいる }\end{array}$ & 6.0 & 5.7 & 7.9 & 7. 4 & 5.6 & 3.5 & 4.7 & 4.8 & 6.2 & 6.0 & 3.7 & 3.4 \\
\hline 5 & $\begin{array}{l}\text { 現在、語学学校等の } \\
\text { その他の教育機関で } \\
\text { 日本語を学んでいる }\end{array}$ & 57.6 & 33.7 & 49.2 & 59.9 & 67.7 & 74. 2 & 58.3 & 34.2 & 51.0 & 58.6 & 69.3 & 73.7 \\
\hline 6 & $\begin{array}{l}\text { 現在、1〜 } 5 \text { の教育 } \\
\text { 機関で日本語を学ん } \\
\text { でいない }\end{array}$ & 28.8 & 49.7 & 32.5 & 24.5 & 22.5 & 17.3 & 31.0 & 50.8 & 33.9 & 29.5 & 24.5 & 19.5 \\
\hline
\end{tabular}

上のデータから応募者の日本語学習の場として、半数以上が語学学校で行ったこと が分かった。 


\section{劉 礪志：2012 年度香港・マカオ日本語能力試験実施報告}

\section{5 受験目的}

アンケート調査の質問 :

あなた今回の試験を受ける目的を一つ選んで、 $\square に$ 記入してください。 アンケートの結果 :

表 9 受験目的

\begin{tabular}{|c|c|c|c|c|c|c|c|c|c|c|c|c|c|}
\hline & & & 管えの & 比率 \% & $6(7)$ & 試験 & & & ええの & 北率 \% & $(12)$ & 月試験 & \\
\hline & 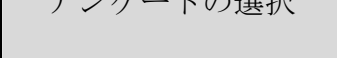 & 全体 & N1 & N2 & N3 & N4 & N5 & 全体 & N1 & N2 & N3 & N4 & N5 \\
\hline 1 & $\begin{array}{l}\text { 大学や大学院入学に必 } \\
\text { 要（自分の国で） }\end{array}$ & 2.5 & 2.7 & 3.0 & 2.6 & 1.9 & 2.5 & 2.4 & 2.0 & 2.5 & 2.5 & 2.4 & 2.4 \\
\hline 2 & $\begin{array}{l}\text { 大学や大学院入学に必 } \\
\text { 要 (日本で) }\end{array}$ & 2.6 & 4.0 & 3.2 & 2.5 & 1.6 & 1.8 & 2.5 & 3.6 & 3.3 & 1.9 & 2.1 & 1.9 \\
\hline 3 & $\begin{array}{l}\text { その他の教育機関での } \\
\text { 入学や能力証明に必要 } \\
\text { (自分の国で) }\end{array}$ & 1.9 & 0.9 & 2.2 & 1.7 & 1.8 & 2.9 & 2.0 & 1.4 & 1.7 & 2.3 & 2.0 & 2.7 \\
\hline 4 & $\begin{array}{l}\text { その他の教育機関での } \\
\text { 入学や能力証明に必要 } \\
\text { (日本で) }\end{array}$ & 1.5 & 1.1 & 1.9 & 1.5 & 1.9 & 1.1 & 1.5 & 0.9 & 2.9 & 1.3 & 1.0 & 1.5 \\
\hline 5 & $\begin{array}{l}\text { 自分の仕事やこれから } \\
\text { の就職・昇給・昇進に } \\
\text { 役立つ（自分の国で） }\end{array}$ & 16.8 & 23.0 & 19.6 & 16.2 & 13.9 & 12.2 & 16.9 & 22.3 & 20.2 & 14.7 & 14.9 & 13.2 \\
\hline 6 & $\begin{array}{l}\text { 自分の仕事やこれから } \\
\text { の就職・昇給・昇進に } \\
\text { 役立つ（日本で） }\end{array}$ & 1.8 & 2.8 & 1.5 & 1.7 & 2.0 & 1.0 & 1.9 & 2.6 & 2.1 & 2.2 & 1.3 & 1. 4 \\
\hline 7 & $\begin{array}{l}\text { 上の } 1 \sim 6 \text { 以外で、自 } \\
\text { 分の実力が知りたい }\end{array}$ & 59. 7 & 57.1 & 58.4 & 61.6 & 61.0 & 60.3 & 59.9 & 57.2 & 56.8 & 64.1 & 61.3 & 60.1 \\
\hline 8 & その他 & 13.2 & 8.4 & 10.2 & 12.2 & 15.9 & 18.2 & 12.9 & 10.0 & 10.5 & 11.0 & 15.0 & 16. 8 \\
\hline
\end{tabular}




\section{6 職業}

アンケート調查の質問 :

あなたの職業について、一つ選んで、 $\square に$ 記入してください。

アンケートの結果 :

表 10 職業

\begin{tabular}{|c|c|c|c|c|c|c|c|c|c|c|c|c|c|}
\hline & & & えの上 & 比率 9 & $(7)$ & 月試験 & & & ええの & 北率 \% & $(12)$ & 月試験 & \\
\hline & & 全体 & N1 & $\mathrm{N} 2$ & N3 & N4 & N5 & 全体 & N1 & $\mathrm{N} 2$ & N3 & N4 & N5 \\
\hline 1 & 小学生（初等教育） & 0.4 & 0.3 & 0.1 & 0.2 & 0.3 & 1.3 & 0.3 & 0.0 & 0.1 & 0.2 & 0.1 & 0.8 \\
\hline 2 & $\begin{array}{l}\text { 中学生・高校生（中等 } \\
\text { 教育） }\end{array}$ & 11.5 & 3.5 & 6.6 & 12.1 & 15.6 & 18.9 & 10.0 & 2.6 & 5.7 & 9.3 & 11.9 & 18. 8 \\
\hline 3 & $\begin{array}{l}\text { 大学・大学院生（高等 } \\
\text { 教育） }\end{array}$ & 21.2 & 23.9 & 26.6 & 21.1 & 17.0 & 17.8 & 18.7 & 19.0 & 23.0 & 21.5 & 16.7 & 14.4 \\
\hline 4 & $\begin{array}{l}\text { 語学学校等のその他の } \\
\text { 教育機関の学生 }\end{array}$ & 3.3 & 2.4 & 4. 1 & 3.4 & 3.4 & 3.1 & 3.5 & 3.5 & 3.6 & 3.7 & 3.3 & 3.7 \\
\hline 5 & $\begin{array}{l}\text { 就業（会社員・公務 } \\
\text { 員・教員・自営等） }\end{array}$ & 57.1 & 62.5 & 55.9 & 56.5 & 57.1 & 54.1 & 59.8 & 64.6 & 59.9 & 57.8 & 60.6 & 56.5 \\
\hline 6 & その他 & 6.5 & 7.4 & 6.7 & 6.7 & 6.6 & 4.8 & 7.7 & 10.3 & 7.7 & 7.5 & 7. 4 & 5.8 \\
\hline
\end{tabular}

\section{6.1 職業の種類}

アンケート調査の質問：職業で 5 を選んだ人に聞きます。

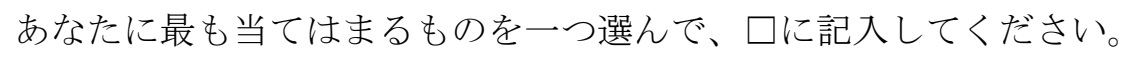
アンケートの結果 : 
劉 礪志：2012 年度香港 - マカオ日本語能力試験実施報告

表 11 職業の種類

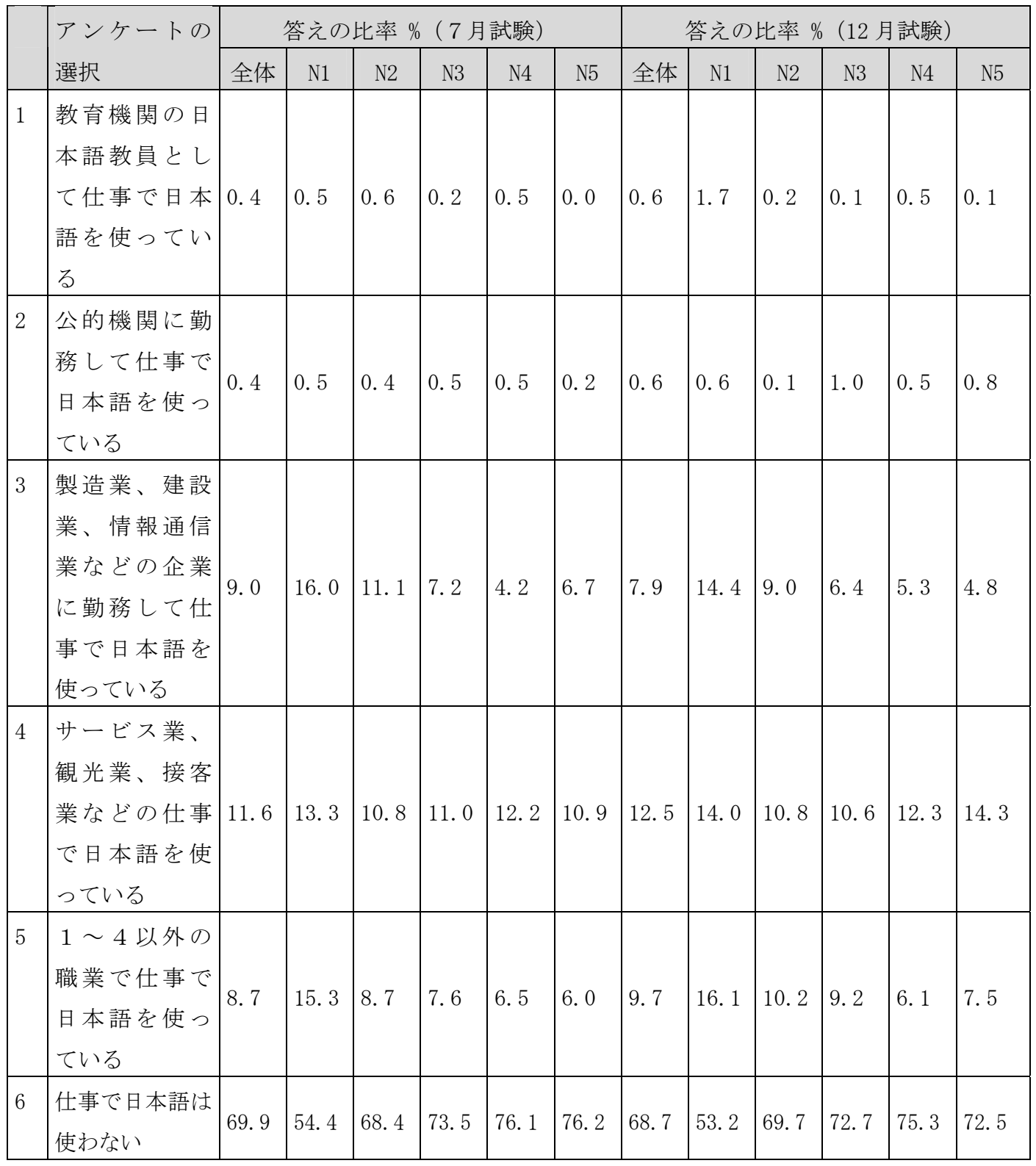


仕事のために受験するという傾向ではないと上 3 . 5 の「受験目的」で分かったが、 こちらの「職業の種類」のデータから見ると、「仕事で日本語は使わない」項目を 70\%選択されたということは受験者は仕事のためでなく本当に自分の実力を証明した いかもしれない。

\section{7 日本語との接触媒体（メディア）}

\section{アンケート調査の質問 :}

あなたは教室の外で何を通じて日本語を聞いたり読んだりしますか。当てはまるも のを選んで、○で囲んでください。

アンケートの結果 :

表 12 日本語との接触媒体（メディア）

\begin{tabular}{|c|c|c|c|c|c|c|c|c|c|c|c|c|c|}
\hline & \multirow{2}{*}{$\begin{array}{l}\text { アンケートの } \\
\text { 選択 }\end{array}$} & \multicolumn{6}{|c|}{ 答えの比率 \%（7 月試験） } & \multicolumn{6}{|c|}{ 答えの比率 \%（12 月試験） } \\
\hline & & 全体 & N1 & N2 & N3 & N4 & N5 & 全体 & N1 & N2 & N3 & N4 & N5 \\
\hline 1 & $\begin{array}{l}\text { ニュース・ド } \\
\text { キュメンタリ } \\
\text { ー }\end{array}$ & 24.8 & 40.8 & 29.6 & 22.0 & 18.3 & 15.6 & 23. 1 & 36.3 & 30.6 & 21.5 & 16.5 & 13.3 \\
\hline 2 & $\begin{array}{l}\text { ドラマ }(ア= \\
\text { メを除く })\end{array}$ & 76.5 & 77. 1 & 79.2 & 78. 7 & 75.2 & 72.5 & 75.9 & 76.4 & 79.3 & 77.8 & 75.6 & 70.8 \\
\hline 3 & アニメ & 56.8 & 54.2 & 58.6 & 56.1 & 56.3 & 58.6 & 56.5 & 55.1 & 56.8 & 57.7 & 56.2 & 56.8 \\
\hline 4 & $\begin{array}{l}\text { 新聞 · 杂倠 } \\
(\text { 誌 } \\
\text { (漫 画を除 } \\
\text { () }\end{array}$ & 42.2 & 51.5 & 47.1 & 43.5 & 36.5 & 33.7 & 39.7 & 49.3 & 43.8 & 38.5 & 35.0 & 33.3 \\
\hline 5 & $\begin{array}{l}\text { 本（教科書を } \\
\text { 除く） }\end{array}$ & 31.6 & 48.9 & 36.9 & 30.5 & 25.4 & 18.9 & 30.3 & 47. 1 & 36.5 & 29.0 & 22.9 & 18.8 \\
\hline 6 & 漫画 & 38.5 & 42.2 & 41.4 & 38.3 & 35.8 & 35.2 & 36.8 & 41.5 & 39.1 & 37.0 & 33.6 & 33.8 \\
\hline 7 & $\begin{array}{l}\text { ヴェブサイト } \\
\text { の記事 }\end{array}$ & 54.8 & 64.3 & 58.9 & 57.8 & 50.0 & 44. 6 & 52.5 & 63.3 & 58.2 & 54.2 & 46. 4 & 43.0 \\
\hline 8 & その他 & 19.2 & 21.5 & 19.9 & 18.3 & 18.1 & 18.4 & 19.9 & 21.7 & 19.9 & 17.2 & 19.4 & 20.9 \\
\hline 9 & $\begin{array}{l}\text { 教室外で日本 } \\
\text { 語にふれて、 } \\
\text { 聞いたり読ん } \\
\text { だりしない }\end{array}$ & 4. 4 & 2.5 & 3.5 & 4.5 & 4.9 & 6.5 & 4. 1 & 3.8 & 3.1 & 4.7 & 4.6 & 4.3 \\
\hline
\end{tabular}




\section{劉＼cjkstart礪志：2012 年度香港・マカオ日本語能力試験実施報告}

「ドラマ、アニメ、ヴェブサイトの記事、雑誌、マンガ…」ような人気順は当然 といえば当然かも知れないが、かつては二三の位を争っていたはずの日本の「マン ガ」はインターネットの普及とともに「ヴェブサイトの記事」に追い越され、なお、 日本語学習においてかなり役立ち、しかもより高いレベルの日本語と接することがで きる、「ニュース・ドキュメンタリー」はそれほど人気ではないこともこのアンケー トで分かった。

\section{8 日本語を使用する相手}

\section{アンケート調査の質問 :}

日常的に、誰に対して日本語を使いますか。当てはまるものを選んで、○で囲んで ください。いくつ選んでもいいです

$$
\text { アンケートの結果: }
$$

\section{表 13 日本語を使用する相手}

先生

\begin{tabular}{|c|c|c|c|c|c|c|c|c|c|c|c|c|c|}
\hline & \multirow{2}{*}{ アンケートの選択 } & \multicolumn{6}{|c|}{ 答えの比率 \% （7 月試験） } & \multicolumn{6}{|c|}{ 答えの比率 \% （12 月試験） } \\
\hline & & 全体 & N1 & $\mathrm{N} 2$ & N3 & N4 & N5 & 全体 & N1 & $\mathrm{N} 2$ & N3 & N4 & N5 \\
\hline 1 & 先生と話す & 57.2 & 51.7 & 61.3 & 60.5 & 56.4 & 55.6 & 55.0 & 50.0 & 57.6 & 55.2 & 55.5 & 56.3 \\
\hline 2 & 先生の話を聞く & 57.7 & 46.4 & 58.6 & 61.6 & 60.1 & 60.5 & 57.0 & 45.5 & 57.3 & 57.9 & 61.6 & 60.8 \\
\hline 3 & 先生が書いたものを読む & 29.6 & 26.0 & 31.2 & 32.0 & 29.1 & 29.6 & 28.6 & 24.5 & 30.8 & 29.0 & 30.0 & 28.3 \\
\hline 4 & 先生に対して文章を書く & 29.5 & 28.2 & 32.5 & 35.0 & 27.2 & 25.1 & 28.7 & 28.4 & 32.7 & 30.4 & 26.9 & 25.8 \\
\hline 5 & どれにも当てはまらない & 30.1 & 41.0 & 28.5 & 26.8 & 27.7 & 28.0 & 31.8 & 43.8 & 31.5 & 30.0 & 27.6 & 27.6 \\
\hline
\end{tabular}

友人

\begin{tabular}{|c|c|c|c|c|c|c|c|c|c|c|c|c|c|}
\hline & \multirow{2}{*}{ アンケートの選択 } & \multicolumn{6}{|c|}{ 答えの比率 \%（7 月試験） } & \multicolumn{6}{|c|}{ 答えの比率 \%（12 月試験） } \\
\hline & & 全体 & N1 & $\mathrm{N} 2$ & N3 & N4 & N5 & 全体 & N1 & N2 & N3 & N4 & N5 \\
\hline 1 & 友人と話す & 46.3 & 56.9 & 48.0 & 46.1 & 40.7 & 41.2 & 46.3 & 55.2 & 50.6 & 44.1 & 42.7 & 40.1 \\
\hline 2 & 友人の話を聞く & 32.9 & 42.3 & 36.6 & 31.9 & 27.5 & 27.8 & 31.6 & 40.1 & 36.6 & 29.6 & 27.8 & 25.1 \\
\hline 3 & 友人が書いたものを読む & 18.9 & 27.0 & 21.6 & 21.1 & 14. 4 & 12.1 & 18.6 & 27.9 & 21.3 & 18.2 & 15.3 & 11.7 \\
\hline 4 & 友人に対して文章を書く & 18.6 & 28.1 & 21.8 & 19.8 & 13.0 & 12.1 & 18.7 & 29.6 & 21.2 & 17.8 & 14.8 & 12.1 \\
\hline 5 & どれにも当てはまらない & 42.7 & 32.5 & 39.4 & 42.3 & 48.6 & 49.0 & 43.5 & 34.4 & 39.3 & 44.7 & 46.2 & 51.3 \\
\hline
\end{tabular}


家族

\begin{tabular}{|c|c|c|c|c|c|c|c|c|c|c|c|c|c|}
\hline & \multirow{2}{*}{ アンケートの選択 } & \multicolumn{6}{|c|}{ 答えの比率 \%（7 月試験） } & \multicolumn{6}{|c|}{ 答えの比率 \%（12 月試験） } \\
\hline & & 全体 & N1 & $\mathrm{N} 2$ & N3 & $\mathrm{N} 4$ & N5 & 全体 & N1 & N2 & N3 & N4 & N5 \\
\hline 1 & 家族と話す & 7.2 & 5.4 & 7.0 & 8.0 & 6.4 & 9.0 & 7.4 & 7.5 & 7.4 & 6.3 & 7.9 & 7.6 \\
\hline 2 & 家族の話を聞く & 3.7 & 3.5 & 3.9 & 3.4 & 3.5 & 4.1 & 4.0 & 5.0 & 4.7 & 2.8 & 3.9 & 3.5 \\
\hline 3 & 家族が書いたものを読む & 1.3 & 1.4 & 1.4 & 1.0 & 1.5 & 1.2 & 1.3 & 1.5 & 1.6 & 1.1 & 1.4 & 1.1 \\
\hline 4 & 家族に対して文章を書く & 1.1 & 1.3 & 1.3 & 0.8 & 1.3 & 0.9 & 1.3 & 1.6 & 1.2 & 1.1 & 1.5 & 1.2 \\
\hline 5 & どれにも当てはまらない & 91.3 & 93.1 & 90.7 & 91.0 & 92.1 & 89.8 & 91.1 & 91.1 & 90.9 & 92.8 & 90.5 & 90.7 \\
\hline
\end{tabular}

上司

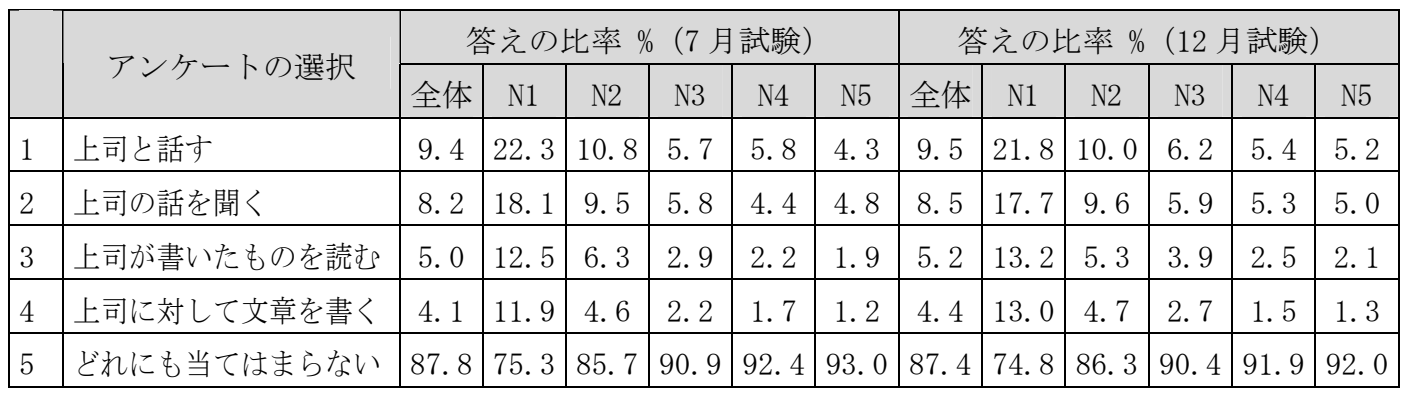

同僚

\begin{tabular}{|c|c|c|c|c|c|c|c|c|c|c|c|c|c|}
\hline & & & 等え0 & 比率 & $6(7$ & | 試験， & & & :えの上 & 匕率 \% & $(12)$ & 験） & \\
\hline & & 全体 & N1 & N2 & N3 & N4 & N5 & 全体 & N1 & N2 & N3 & N4 & N5 \\
\hline 1 & 同僚と話す & 11.7 & 23.2 & 12.5 & 8.4 & 7.9 & 8.0 & 11.9 & 22.7 & 12.2 & 8.3 & 9.0 & .5 \\
\hline 2 & 同僚の話を聞く & 9.1 & 19.0 & 10.3 & 6.6 & 5.1 & 6.0 & 9.4 & 18.0 & 10.7 & 6.0 & 6.7 & 6.6 \\
\hline 3 & 同僚が書いたものを読む & 5.5 & 13.7 & 5.7 & 3.3 & & & 5.3 & 12.5 & 5.0 & 4.2 & & 2.7 \\
\hline 4 & 同僚に対して文章を書く & 4.4 & 12.3 & 4.9 & 2.6 & 1.9 & 1.7 & 4.3 & 11.9 & 3.9 & 3.2 & 1.6 & 1.7 \\
\hline 5 & どれにも当てはまらない & 85.3 & 74.1 & 83.3 & 88.5 & 90.4 & 88.9 & 84.9 & 74.1 & 84.3 & 88.1 & 88.1 & 88.9 \\
\hline
\end{tabular}

顧客

\begin{tabular}{|c|c|c|c|c|c|c|c|c|c|c|c|c|c|}
\hline & & & 答え0 & $\%$ & 6 & () & & & え & $\%$ & (1 & 検） & \\
\hline & & 全体 & N1 & $\mathrm{N} 2$ & N3 & N4 & N5 & 全体 & N1 & $\mathrm{N} 2$ & N3 & N4 & N5 \\
\hline 1 & 顧客と話す & 15.4 & 26.2 & 17.3 & 12.9 & 11.2 & 10.9 & 16.6 & 26.1 & 16.8 & 14.7 & 13.3 & 13.5 \\
\hline 2 & 顧客の話を聞く & 12.3 & 21.1 & 13.8 & 10.4 & 8.8 & 8.6 & 13.3 & 20.4 & 14.0 & 11.1 & 10.6 & 11.2 \\
\hline 3 & 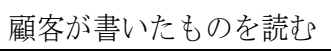 & 5.4 & 12.5 & 6.9 & 3.7 & & & 5.7 & 12.7 & 6.2 & .4 & & 2.3 \\
\hline 4 & 顧客に対して文章を書く & 4.5 & 12.0 & 5.1 & 3.0 & 1.6 & 17 & 4.6 & 12.0 & 5.2 & 3.4 & 1.9 & 1.7 \\
\hline 5 & どれにも当てはまらない & 81.3 & 70.2 & 78.9 & 83.8 & 85.8 & 86.6 & 79.4 & 70.0 & 78.7 & 81.6 & 82.8 & 82.8 \\
\hline
\end{tabular}




\section{劉＼cjkstart礪志：2012 年度香港・マカオ日本語能力試験実施報告}

\section{まとめ}

日本語能力試験の受験者数減少の原因はいろいろあるようだ。一方、日本語学習者 の増減がまさに日本そのものに対する好感度を如実に反映している。近年、日本の環 境や経済、他の国の世界的進出など、著しい変化が続々出てきているため今後それら に目を向け適切な姿勢を構えなければならないだろう。 